Journal of Economics and Behavioral Studies

Vol. 2, No. 5, pp. 191-198, May 2011

\title{
A Comparative Study of Strategic Human Resource Management Practices by Linking People with Strategic Needs of Business
}

\author{
AKM Mominul Haque Talukder \\ School of Business, North South University, Dhaka 1229, Bangladesh \\ momin@northsouth.edu
}

\begin{abstract}
The purpose of this research is to test and contrast whether or not strategic human resource management (SHRM) can be used to predict economic development i.e., efficiency and organizational development of two real estate company located in Dhaka, Bangladesh. Convenience sampling method was applied to obtain data from 100 employees. The study reveals no relationship of SHRM with economic development and organizational development. HR policies is negatively related with economic development while no relationship with organizational development in case of Oriental Ltd (OL) while for Suvastu Ltd (SL), it is negatively related with organizational development but has no relationship with economic development. Correspondingly, HR process is negatively related with economic development but positively related with organizational development in case of OL while HR processes have no relationship in case of SL. HR development has no relationship with economic development and organizational development for both the firms. HR practices have less or no strategic significance for the given organizations. HR outsourcing has no relationship with economic development and organizational development either. The findings suggest that using these dimensions may provide organizations with the potential to improve existing level of efficiency and development of the firms.
\end{abstract}

Keywords: SHRM, HR Policy, HRD, HR Outsourcing, and Organizational Development

\section{Introduction}

The field of strategic human resources management (SHRM) has enjoyed a remarkable ascendancy during the past two decades, as both an academic literature and focus of management practice (Becker \& Huselid, 2006). Strategy is about building sustainable competitive advantage that in turn creates above-average financial performance. The notion that organizations can build competitive advantage, and as a result above-average financial performance, based on valuable and inimitable internal resources, offers an appealing rationale for HR's strategic importance. The human resource function has consistently faced a battle in justifying its position in organizations. In times of plenty, firms easily justify expenditures on training, staffing, reward, and employee involvement systems, but when faced with financial difficulties, such as HR systems fall prey to the earliest cutbacks (Mello, 2006).

Boxall (1996) suggested that human resources advantage consists of two parts. First, human capital advantage refers to the potential to capture a stock of exceptional human talent "latent with productive possibilities." Human process advantage can be understood as a "function of causally ambiguous, socially complex, historically evolved processes such as learning, cooperation and innovation." He argued that one major task of organizations is the management of mutuality (i.e., alignment of interests) to create talented and committed workforce. A second task is to develop employees and teams in such a way as to create an organization capable of learning within and across industry cycles. Successful accomplishment of this task results in the organizational process advantage. Lepak and Snell (1999) presented an architectural approach to SHRM based at least partly in the RBV (resource based view). They proposed that within organizations, considerable variance exists with regard to both the uniqueness and value of skills. They helped SHRM researchers recognize that real and valid variance exists in HR practices within the organizations, and looking for one HR strategy may mask important differences in the types of human capital available to firms (Truss \& Gratton, 1994). By and large, some goals of this research are such as (i) to understand strategic human resource management and its relevance to managers and employees in organizations; (ii) to apply relevant theories to the management of people in real estate sector and analyze business challenges involving strategic 
human resource management; (iii) to assess critically and to evaluate strategic human resource management policies and practices; and (iv) to achieve competitive advantages by practicing SHRM in different organizations and how these advantages lead a company to sustain long term benefit. It is surprising that the effect of Strategic HRM, HR policy and process, HR outsourcing and HR development on economic and organizational advancement in the organizations has not been examined more thoroughly within a work context in Bangladesh. In this research, attempts have been undertaken to fill this void in literature review by examining the impact of SHRM and HR systems on organizational and economic development in two real state firms.

\section{Review of Literature and Hypothesis Development}

Conceptual development within the field of SHRM has leveraged the RBV to achieve some consensus on the areas within the human resource architecture in which sustainable competitive advantage might be achieved (Lepak \& Snell, 1999). First, human capital pool refers to the stock of employee skills that exist within a firm at any given point in time. Theorists focus on the need to develop a pool of human capital that has either higher levels of skills or achieving a better alignment between the skills represented in the firm and those required by its strategic intent. The actual stock of human capital can and does change over time, and must constantly be monitored for its match with the strategic needs of the firm. Second, an increasing consensus is emerging among researchers that employee behavior is an important independent component of SHRM (Mello, 2006). Distinct from skills of the human capital pool, employee behavior recognizes individuals as cognitive and emotional beings who posses free will. This free will enables them to make decisions regarding the behaviors in which they will engage. Firms may have access to valuable human capital, either through the poor design of work or the mismanagement of people may not adequately deploy it to achieve strategic impact.

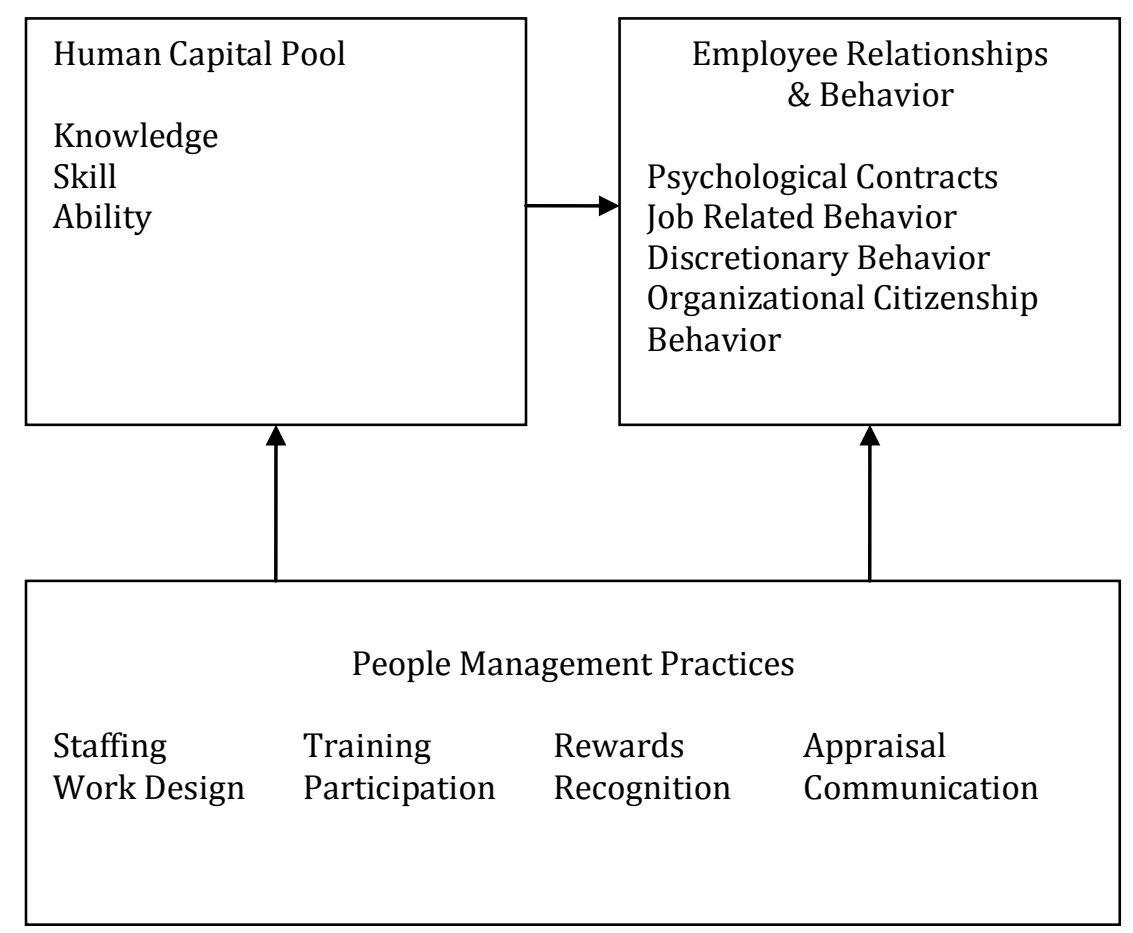

Figure 1. A Model of the Basic Strategic HRM components (Adopted from Lepak \& Snell, 1999)

Economic Development: A study sponsored by the Society for Human Resource Management (SHRM) and Global Consulting Alliance found that HR's success as a true strategic business partner was dependent on five specific competencies being displayed by HR (Meisinger, 2003). The first, strategic contribution requires the development of strategy, connecting organizations to external constituents, and implementing systems that 
align employee performance with company strategy. The second, business knowledge, involves understanding the nuts and bolts of the organization's operations and leveraging this knowledge into results. The third, personal credibility, requires that measurable value be demonstrated in programs and policies implemented. The fourth, HR delivery, involves serving internal customers through effective and efficient programs related to staffing, performance management, and employee development. The fifth, HR technology, involves using technology to improve the organization's management of its people.

Organizational Development (OD): OD comprises the long range efforts and programs aimed at improving an organization's ability to survive by changing its problem-solving and renewal processes. It involves moving toward an adaptive organization and achieving corporate experience by integrating the desires of individuals for growth and development with organizational goals (Brown \& Harvey, 2006). Organization development is an emerging discipline aimed at improving the effectiveness of the organization and its members by means of a systematic change program. Chester Barnard and Chris Argyris have noted that the truly effective organization is one in which both the organization and the individual can grow and develop. What makes one organization a winner, whereas another fails to make use of the same opportunities? The key to survival and success lies not in rational, quantitative approaches, but rather in a commitment to irrational, difficult-to-measure things like people, quality, customer service, and most important, developing the flexibility to meet changing conditions. For example, in a study that examined the "high-tech/high-touch" phenomenon at Citigroup, the crucial component in adapting to technological change was the human factor (Brown \& Harvey, 2006). Employee involvement and commitment is the true key to successful change.

Strategic Human Resource Management: Strategic human resource management (SHRM) is concerned with the relationship between an organization's strategic management and the management of its human resources (Boxall, 1996). Gerhart (2005) has recently suggested that SHRM moves closer to the individual level by emphasizing HR's impact on employee relations and attitudes. Effective organizations are increasingly realizing that of the varied factors that contribute to performance, the human element is clearly the most critical (Mello, 2006). Managers at all levels in organizations are becoming increasingly aware that a critical source of competitive advantage often comes not form having the most ingenious product design or service, the best marketing strategy, state-of-the art technology, or the most savvy financial management but from having the appropriate systems for attracting, motivating, and managing the organizations' human resources (Mello, 2006). Thus,

Hypothesis 1: Strategic HRM is positively related with economic development and organizational development in the given firms

Human Resources Policy: Human Resources policies establish guidelines for action on people-related business issues and HR programs (Mello, 2006). People-related business issues are those that affect the immediate and future success of the business and involve people. Flowing from the strategic business needs they may include the need to hire skilled workers, the need to improve worker productivity, or the need to reduce health care costs. Other business issues include the need to develop a top cadre of international managers, the need to have an adaptable and skilled workforce under changing environmental conditions, and the need to reduce excessive turnover of younger, talented individuals who are blocked by the limited number of traditional promotion opportunities.

Hypothesis 2: HR policy has positive effect on economic development and organizational development in the given firms

Human Resources Process: It deals with how HR activities are identified, formulated, and implemented. Workers need to know how their own activities contribute to organizational performance and see a clear link between their efforts and (as individuals or as part of a team) and rewards (Marchington \& Wilkinson, 2008). Boxall (1998) makes the distinction between 'human capital advantage' (a stock of exceptional human talent latent with productive possibilities) and 'organizational process advantage' (causally ambiguous, socially complex, historically evolved process - such as learning and cooperation - that emerge and are difficult to imitate). Each element is therefore important, whether it is an individual's inherent ability to learn or their 
manual dexterity, or the HR policies or practices that are implemented in order to recruit, motivate or develop people at work. It is therefore clear that the employment of highly qualified or talented people can be useless without effective HR processes to ensure that they work well in teams are keen to contribute to organizational goals (Wright et al., 1994). Similarly, a set of HR practices that fits well with the high commitment bundle is useless if supervisors and staff show little interest in using their discretion at work.

Hypothesis 3: HR process is positively related with economic development and organizational development in the given firms

Human Resource Development (HRD): McLagan (1989) postulated a much larger scope for HRD by defining it as "the integrated use of training and development, organization development, and career development to improve individual, group, and organizational effectiveness." Watkins (1991) supported this expansive understanding of the field by defining HRD as a field that fosters the long-term, work-related learning capacity at individual, group, and organizational levels, including, but not limited to, organization development, career development, and training and development-the same areas as identified by McLagan (1989). Swanson's (1995) definition of HRD was "a process of developing and/or unleashing human expertise through organization development and personnel training and development for the purpose of improving performance." Donovan and Marsick (2000) pointed to the increasing application and incorporation of other fields of study into the common understanding of HRD, including organizational leadership, organizational values, workforce development (Holton \& Naquin, 2002; Jacobs, 2000) at the societal level, and labor economics. A recent definition proposed by Dilworth (2003) suggested that subfields, such as strategic change management, integration of learning processes, knowledge management, career development, healthy and productive workplaces, insourcing and outsourcing of training, team building, leadership development, and application of technologies to HRD, should all be subsumed within the HRD discipline; but the definition still did not extend beyond an organizational focus.

Hypothesis 4: HR development has positive effect on economic and organizational development in the given firms

Human Resource Outsourcing: The form of HR delivery has become much more popular in the last 10 years. For example, a PricewaterhouseCoopers survey in 2002 reported that over $70 \%$ of organizations outsourced at least one aspect of their HR work compared with a little less than $50 \%$ two years earlier, and this is likely to have grown consistently since then (Marchington \& Wilkinson, 2008). The market for providers of outsourced services of all types is growing rapidly. The 1997 Survey of Human Resource trends of 1,700 organizations reported that 53 percent planned to outsource more in the future (Carney, 1997). HR departments are facing the classic make-or-buy decisions that other functional areas confront when considering the outsourcing of services or products. Charles et al. (1999) identified five competitive forces that are driving more companies to outsource some or all of their HR activities: downsizing, rapid growth or decline, globalization, increased competition, and restructuring. Over the past decade, these forces have significantly altered the strategy and structure of many firms. During this time firm have attempted to refocus their costs while increasing service, and improve capabilities to respond to future business challenges. The

global imperatives for outsourcing accelerates as firms evolve from sellers of products and services abroad to setting up operations in foreign countries and staffing those operations with host country or third party nationals. Strategically, outsourcing provides HR departments with a tool of producing competitive advantage for the firm. HR outsourcing decisions can potentially be part of a large pattern of responses designed to deliver hard-to-imitate, hard-to-substitute, value-added services that enhance the value and quality of the firm's products and services (Pfeffer, 1997).

Hypothesis 5: HR outsourcing is positive related with economic development and organizational development in the given firms

\section{Conceptual Framework}

A model is tested that derived from a review of the literature integrating theory and research relating to work environments, insomnia, emotions and their relationship to job satisfaction. Lack of good work environment 
has been shown to be an enabling factor for dissatisfaction in the workplace. Correspondingly, increased level of insomnia as employees got to work for extended period of time is likely to impact their mindset consequently impacting the level of job satisfaction negatively. Likewise, hostility and fatigue decreases the level of job satisfaction while joviality and attentiveness increases the level of job satisfaction.

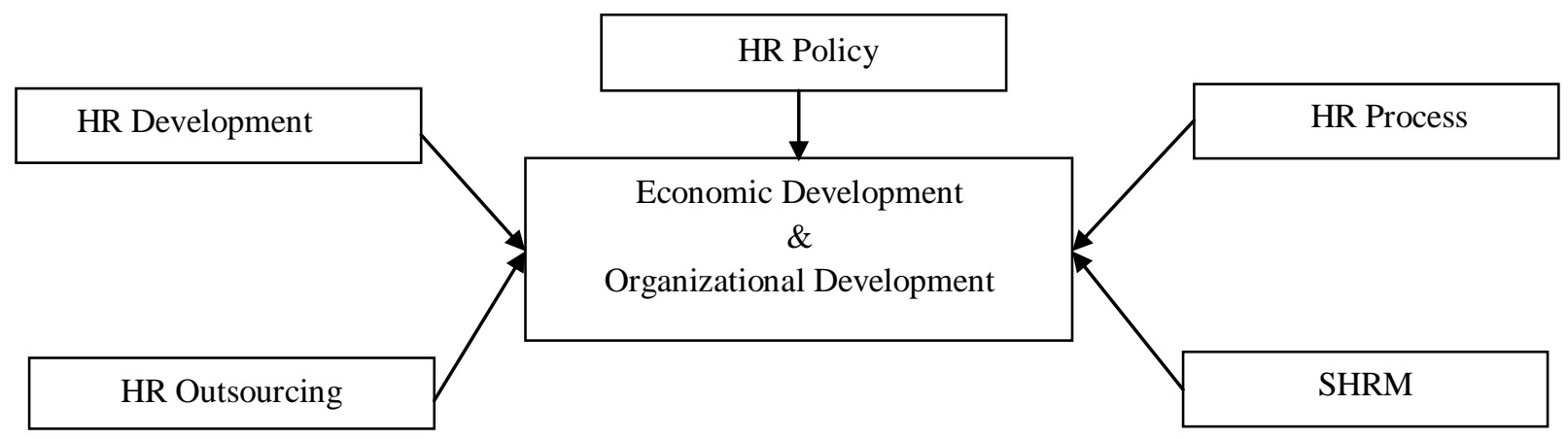

Figure 2: Conceptual framework of research variables and their relationships

\section{Methods}

Convenience sampling method was used to select the participants. The sample size was 100 . The key participants were management staffs of two real estate firms (e.g., Oriental Ltd and Suvastu Ltd) in Dhaka, Bangladesh. All the questions in the survey format were of 5-point Likert Scale ranging from 1 (Strongly Disagree) to 5 (Strongly Agree). All the participants were given a letter, attached to the questionnaire from the author explaining the context of the research. No information was asked on the identity or contact information of the respondents. Dependent variable was the presumed cause of some change in independent variable. The independent variables are SHRM (Strategic HRM), HR policy, HR process, HR development, and HR outsourcing and dependent variables are economic development, and organizational development.

\section{Results and Discussion}

Table 1(a) and Table 1(b) below represent Cronbach's alpha ranges from 0.51 to 0.9 for OL and 0.63 to 0.87 for SL respectively. This value is a prerequisite to know internal consistency of the items both within and among the variables in the given study.

Table 1(a): Reliability Test of Oriental Ltd (OL)

\begin{tabular}{lc}
\hline Constructs & Cronbach's Alpha \\
\hline HR Policy & .63 \\
HR Process & .90 \\
Human Resource Development & .52 \\
Human Resource Outsourcing & .51 \\
Strategic HRM & .54 \\
Economic Development & .51 \\
Organizational Development & .50 \\
\hline
\end{tabular}

Table 1(b): Reliability Test of Suvastu Ltd (SL)

\begin{tabular}{lc}
\hline Constructs & Cronbach's Alpha \\
\hline HR Policy & .87 \\
HR Process & .75 \\
Human Resource Development & .66 \\
Human Resource Outsourcing & .80 \\
Strategic HRM & .70 \\
Economic Development & .63 \\
Organizational Development & .66 \\
\hline
\end{tabular}


Hypothesis 1 predicts that strategic HRM is positively related with economic development and organizational development. The study finds no relationship of SHRM with economic development and organizational development across Table 2(a) and Table 2(b) below. Hence, the hypothesis is rejected for OL but accepted for SL. This can be justified by Wright et al. (1994) where they argued that instead of applying the concepts of value, rareness, inimitability, and substitutability, HR practice could be easily copied by competitors. HR practices have less or no strategic significance for the given organizations.

Table 2(a): Mean, Standard Deviation, and Correlation of variables of employees of OL

\begin{tabular}{llllllllll}
\hline Variables & Mean & SD & 1 & 2 & 3 & 4 & 5 & 6 & 7 \\
\hline 1. HR Policy & 1.90 & .32 & & & & & & & \\
2. HR Process & 2.24 & .44 & $.49^{* *}$ & & & & & & \\
3. Economic Development & 3.49 & .41 & $.5^{* *}$ & $.74^{* *}$ & & & & & \\
4. HR Development & 2.88 & .39 & .06 & .2 & .26 & & & & \\
5. HR Outsourcing & 3.16 & .38 & .06 & .3 & .13 & $.9^{* *}$ & & & \\
6. SHRM & 2.67 & .34 & .24 & $.61^{* *}$ & .1 & .32 & $.36^{*}$ & & \\
7. Organizational Development & 3.98 & .36 & .15 & $.38^{*}$ & .2 & .02 & .06 & .27 & \\
\hline Notgizina
\end{tabular}

Notes: $N=50 ;{ }^{* *} p<.01,{ }^{*} p<.05$

Hypothesis 2 predicts that HR policies have positive effect on economic development and organizational development. As presents across table 2(a) and Table 2(b) that HR policies is negatively related significantly with economic development while no relationship with organizational development in case of OL while for SL, HR policy is negatively related significantly with organizational development but no relationship with economic development. Thus the hypothesis is rejected. HR policy is most likely to be perceived as an authority situation when the HRM function is perceived as high-status, high-credibility function and activity (Kelman \& Hamilton, 1989). This is most likely when HRM has significant and visible top management support in the firm and can be achieved through investments in HR practices.

Hypothesis 3 predicts that HR process is positively related with economic development and organizational development. As displayed across Table 2(a) and Table 2(b) that HR process is negatively related significantly with economic development but positively with organizational development in case of OL while HR policies have no relationship in case of SL. Thus the hypothesis is rejected. Given a desired content of the HRM system, it still may not elicit appropriate collective behaviors and attitudes needed for effectiveness because individuals may interpret the HRM practices idiosyncratically, leading to variability in psychological climate perceptions (Rousseau, 1995).

Hypothesis 4 predicts that HR development has positive effect on economic and organizational development. As shown across table 2(a) and 2(b) that HR development has no relationship with economic development and organizational development. Thus, the hypothesis is rejected. McLagan (1989) noted that the integrated use of training and development, organization development, and career development are required to improve individual, group, and organizational effectiveness without which HR development may not be flourished in the studied firms.

Table 2(b): Mean, Standard Deviation, and Correlation of variables of SL

\begin{tabular}{|c|c|c|c|c|c|c|c|c|c|}
\hline Variables & Mean & SD & 1 & 2 & 3 & 4 & 5 & 6 & 7 \\
\hline 1. HR Policy & 2.40 & .60 & & & & & & & \\
\hline 2. HR Process & 2.38 & .54 & $.99^{* *}$ & & & & & & \\
\hline 3. Economic Development & 4.17 & .43 & .14 & .22 & & & & & \\
\hline 4. HR Development & 3.80 & .38 & .03 & .11 & $.65^{* *}$ & & & & \\
\hline 5. HR Outsourcing & 4.57 & .44 & $.39 *$ & $.34 *$ & $.4^{*}$ & $.36^{*}$ & & & \\
\hline 6. SHRM & .33 & $.5^{* *}$ & $.43 *$ & .3 & $.35^{*}$ & $.55^{* *}$ & & & \\
\hline 7. Organizational Development & 4.46 & .33 & $.35^{*}$ & .32 & .3 & .31 & $.56^{* *}$ & $.64^{* *}$ & \\
\hline
\end{tabular}

Notes: $N=50 ;{ }^{* *} p<.01,{ }^{*} p<.05$ 
Hypothesis 5 predicts that HR outsourcing is positive related with economic development and organizational development. As presented across table 2(a) and table 2(b) that HR outsourcing has no relationship with economic development and organizational development. Though the hypothesis is rejected but this can be justified by the fact that outsourcing can be helpful for the company to focus on its own core competence, and it is acknowledged that there is a great possibility that its vital information may be leaked our to its suppliers. According to Hamel (1991), core competence or core skills can be both maintained and lost in strategic alliances. Skills can be learnt from the other party and absorbed into one's own company; in the same way, one's own skills can pass to a partner and unique competitive advantages are lost.

\section{Conclusion and Implications}

The concept and variables presented here proposes that the framework of strategic human resource management is made up of all activities affecting the behavior of individuals in their efforts to formulate and implement the strategic needs of the business. The study did not find significant relationship between the studied variables what it would have been anticipated. Possible causes may be though firms have human resource policies and processes but they fail to streamline them with mainstream business. The study also found lack of partnership and skepticism while carrying out the HR functions. Both firms disclosed proximity in terms of implementing HR practices.

Successful efforts of strategic HR management begin with the identification of strategic business needs. If these needs are important to the success of the business, and if strategic human resources management can be instrumental in meeting these needs, then these needs should be systematically analyzed for their impact on human resources activities, including HR policies, HR programs, HR processes, HR development, and HR outsourcing. Another implication is that because of employees in the studied firms are affected by strategic human resource management, participatory processes may help cement the link between strategy and HR practices to achieve organization development. A third implication is that HR departments in both firms have significant opportunity to impact their organizations' efforts to successfully launch strategic initiatives. This study would foster future research in the areas of identifying employee role behavior and linking HR practices to them in mapping the patterns of consistency, within and across the strategic human resources management initiatives.

The sample size is not large. There are two concerns with a small sample size. First, small sample sizes generate low statistical power, meaning that one is more likely to conclude (falsely) that no relationship exists when, in fact, one truly does. This issue is of no particular concern here because nearly all of the statistical tests were based on within-individual relationships, where the number of observations $(N=100)$ was not more than adequate. The other concern with a small sample size is generalizability. Results from small samples are less likely to replicate because of second-order sample error.

\section{Acknowledgement}

The author would like to thank all participants of Oriental Ltd and Suvastu Ltd in Dhaka, Bangladesh for their help with data collection.

\section{References}

Becker, B. E. and Huselid, M. A. (2006). Strategic Human Resource Management: Where do we go from here? Journal of Management. 32(6): 898-925.

Boxall, P. F. (1996). The Strategic HRM debate and the resource-based view of the firm. Human Resource Management Journal, 6(3): 59-75.

Boxall, P. F. (1998). Human resource strategy and industry-based competition: A conceptual framework and agenda for theoretical development. In P.M.Wright, L. D. Dyer, J.W. Boudreau and G.T. Milkovich (Eds.). Research in personnel and human resources management (4: 1-29). Madison, WI: IRRA.

Brown, D. R. \& Harvey, D. (2006). An Experiential Approach to Organizational Development (7th ed.). Prentice Hall. 
Carney, W. (1997). Outsourcing HR and benefits: Navigating the right course, Benefits and Compensation International, 26(7): 15-23.

Charles, R. G., Stuart, A. Y. \& David, A. G. (1999). Human Resource Management Outsourcing: The Make or Buy Decision. Academy of Management Executive, 13(3): 85-96.

Dilworth, L. (2003). Searching for the future of HRD. Advances in Developing Human Resources, 5(3): 241-244.

Donovan, L. L., \& Marsick, V. J. (2000). Trends in literature: A comparative analysis of 1998 HRD research. In K. P. Kuchinke (Ed.), 2000 conference proceedings of the Academy of Human Resource Development (section 40-2). Baton Rouge, LA: AHRD.

Gerhart, B. (2005). Human resources and business performance: Findings, unanswered questions, and an alternative approach. Management Revue, 16 (2): 174-185.

Hamel, G. (1991). Competition for competence and inter-partner learning within international strategic alliances. Strategic Management Journal, 12(Special Issue): 83-103.

Holton, E. F., \& Naquin, S. S. (2002). Preface. Advances in Developing Human Resources. 4(2): 107-110.

Jacobs, R. (2000). Human resource development and the emergence of workforce development: Practical and philosophical implications. Advances in Developing Human Resources. 2(3): 65-70.

Kelman, H. C., \& Hamilton, V. C. (1989). Crimes of obedience: Toward a social psychology of authority and responsibility. New Haven, C T: Yale University Press.

Lepak, D. P., \& Snell, S. A. (1999). The human resource architecture: Toward a theory of human capital allocation and development. Academy of Management Review. 24(1): 31-48.

Marchington, M. \& Wilkinson, A. (2008). Human Resource Management at Work, Chartered Institute of Personnel and Development (CIPD), London.

McLagan, P. A. (1989). Models for HRD practice: The models. Alexandria, VA: American Society for Training and Development.

Meisinger, S. (2003). Adding Competencies, Adding Value. HR Magazine, 48: 7-14.

Mello, J. A. (2006). Strategic Human Resource Management. Thomson, South-Western.

Pfeffer, J. (1997). Pitfalls on the road to measurement: The dangerous liaison of human resources with the ideas of accounting and finance. Human Resource Management. 36(3): 357-365.

Rousseau, D. M. (1995). Psychological contracts in organizations. Thousand Oaks, CA: Sage.

Swanson, R. A. (1995). Human resource development: Performance is the key. Hunan Resource Development Quarterly, 6(2): 207-213.

Truss, C \& Gratton, L. (1994). Strategic human resource management: A conceptual approach. International Journal of Human Resource Management, 5(3): 663-686.

Watkins, K. E. (1991). Many voices: Defining human resource development from different disciplines. Adult Education Quarterly. 41(4): 241-255.

Wright, P. M., McMahan, G. C., \& McWilliams, A. (1994). Human resources and sustained competitive advantage: a resource-based perspective. International Journal of Human Resource Management. 5(2): 301-326. 